Journal of Healthcare Technology and Medicine Vol. 4 No. 1 April 2018

Universitas Ubudiyah Indonesia

e-ISSN : 2615-109X

\title{
FAKTOR-FAKTOR YANG BERHUBUNGAN DENGAN KEJADIAN OBESITAS PADA PELAJAR DI SMA NEGERI 4 BANDA ACEH TAHUN 2018
}

\author{
Factors That Are Related To The Event Of Obesity In Students In State 4 Sma \\ Banda Aceh, 2018 \\ ${ }^{1}$ Syarifah Asyura, ${ }^{2}$ Novi Yanti \\ ${ }^{1,2}$ Fakultas Ilmu Kesehatan, Universitas Ubudiyah Indonesia, Banda Aceh \\ Email:syarifah_a@uui.ac.id, noviyanti@gmail.com
}

\begin{abstract}
ABSTRAK
Obesitas disebabkan oleh ketidakseimbangan antara jumlah energi yang masuk dengan yang dibutuhkan oleh tubuh. Masalah obesitas/overweight pada anak dan remaja dapat meningkatkan kejadian diabetes mellitus (DM) tipe 2. Selain itu, juga berpotensi mengakibatkan gangguan metabolisme glukosa dan penyakit degeneratif seperti penyakit jantung, penyumbatan pembuluh darah dan lain-lain. untuk mengetahui hubungan jenis kelamin, asupan makanan, asupan serat, pola makan dan aktivitas fisik dengan kejadian obesitas pada pelajar di SMAN 4 Banda Aceh Tahun 2018. penelitian bersifat deskriptif analitik dengan desain cross sectional. Pengambilan sampel menggunakan tehnik simple random sampling dengan jumlah 84 responden. Penelitian dilakukan pada tanggal 16 - 30 April 2018 pada pelajar di SMAN 4 Banda Aceh. Cara pengumpulan data dengan mengisi kuesioner, selanjutnya dilakukan uji chi-square dengan tingkat kepercayaan $95 \%$ dan batas kemaknaan $(\alpha=0,05)$ Ha diterima $p$ value $<0,05$. dengan asupan energi lebih mengalami obesitas sebanyak 28 responden $(100 \%)$, responden dengan asupan karbohidrat lebih mengalami obesitas sebanyak 31 responden (100\%), dari 27 responden dengan asupan protein lebih mengalami obesitas sebanyak 25 responden (92,6\%), dari 33 responden dengan asupan lemak lebih mengalami obesitas sebanyak 32 responden (97\%), dari 53 responden dengan asupan serat kurang mengalami obesitas sebanyak 36 responden (67,9\%), dari 39 responden dengan pola makan tidak baik mengalami obesitas sebanyak 27 responden $(69,2 \%)$ dan dari 53 responden yang memiliki aktivitas ringan mengalami obesitas sebanyak 27 responden (50,9\%). hubungan asupan makanan dengan kejadian obesitas $(\mathrm{p}=0,000)$, ada hubungan jenis kelamin dengan kejadian obesitas $(\mathrm{p}=0,006)$, ada hubungan asupan serat dengan kejadian obesitas $(\mathrm{p}=0,001)$, ada hubungan pola makan dengan kejadian obesitas $(\mathrm{p}=0,011)$ dan ada hubungan aktivitas fisik dengan kejadian obesitas $(\mathrm{p}=0,001)$. Diharapkan remaja menghindari obesitas dengan cara menyesuaikan asupan makanan yang dikonsumsi dengan aktivitas fisik, melakukan olahraga rutin, yang disertai dengan asupan makanan, pola makan yang sesuai dengan anjuran kesehatan
\end{abstract}

Kata Kunci : jenis kelamin, asupan makanan, asupan serat, pola makan, aktivitas fisik, obesitas

ABSTRACT

Obesity is caused by an imbalance between the amount of energy that enters what is needed by the body. The problem of obesity / overweight in children and adolescents can increase the incidence of type 2 diabetes mellitus (DM). In addition, it also has the potential to cause impaired glucose metabolism and degenerative diseases such as heart disease, blood vessel blockage and others. to determine the relationship of gender, food intake, fiber intake, diet and physical activity with the incidence of obesity in students at SMAN 4 Banda Aceh in 2018. The study was descriptive analytic with cross sectional design. Sampling using simple random sampling technique with 84 
Journal of Healthcare Technology and Medicine Vol. 4 No. 1 April 2018

Universitas Ubudiyah Indonesia

e-ISSN : 2615-109X

respondents. The study was conducted on April 16-30, 2018 at students at SMAN 4 Banda Aceh. The method of data collection by filling out the questionnaire, then performed a chi-square test with a confidence level of $95 \%$ and a significance limit $(\alpha=0.05)$ Ha accepted $p$ value $<0.05$. with energy intake more obese by 28 respondents (100\%), respondents with carbohydrate intake were more obese by 31 respondents (100\%), out of 27 respondents with protein intake were more obese by 25 respondents (92.6\%), out of 33 respondents with fat intake were more obese as many as 32 respondents (97\%), out of 53 respondents with fiber intake were less obese as many as 36 respondents (67.9\%), out of 39 respondents with poor eating patterns were as many as 27 respondents $(69,2 \%)$ and of the 53 respondents who had mild activity were obese as many as 27 respondents $(50.9 \%)$. relationship between food intake and obesity $(p=0,000)$, there is a sex relationship with obesity $(p=0.006)$, there is a relationship between fiber intake and obesity $(p=$ $0.001)$, there is a relationship between diet and obesity $(p=0.011)$ and there is a relationship between physical activity and the incidence of obesity $(p=0.001)$. It is expected that adolescents avoid obesity by adjusting the intake of food consumed with physical activity, doing regular exercise, which is accompanied by food intake, eating patterns in accordance with health advice

Keywords: gender, food intake, fiber intake, diet, physical activity, obesity

\section{PENDAHULUAN}

Obesitas/overweight telah menjadi pandemi global di seluruh dunia dan dinyatakan oleh

World Health Organization (WHO) sebagai masalah kesehatan kronis terbesar. Obesitas atau yang biasa dikenal sebagai kegemukan merupakan suatu masalah yang cukup merisaukan dikalangan remaja. Obesitas terjadi karena adanya ketidakseimbangan antara energi yang masuk dengan energi yang keluar (Proverawati, 2010).

Pola makan yang berlebih dapat menjadi faktor terjadinya obesitas. Obesitas terjadi jika seseorang mengonsumsi kalori melebihi jumlah kalori yang dibakar. Pada hakikatnya, tubuh memerlukan asupan kalori untuk kelangsungan hidup dan aktivitas fisik, namun untuk menjaga berat badan perlu adanya keseimbangan antara energi yang masuk dengan energi yang keluar. Keseimbangan energi yang terjadi dapat mengarah pada kelebihan berat badan dan obesitas (Sartika, 2011).

Berdasarkan hasil penelitian National Health and Nutrition Examination Survey tahun 2009-2010 di Amerika persentase overweight dan obesitas berdasarkan kelompok umur, anak usia 2-5 tahun sebesar 26,7\%, usia 6-11 tahun sebesar 32,6\% dan usia 12-19 tahun sebesar 33,6\%. Hal ini menunjukkan bahwa prevalensi overweight dan obesitas tertinggi pada anak remaja usia 12-19 tahun. Pada tahun 2009-2010 Asia memiliki prevalensi overweight sebesar 26,4\% pada anak laki-laki dan 16,8\% pada anak perempuan (NOO, 2011).

Indonesia memiliki prevalensi gemuk pada remaja umur 16-18 tahun sebanyak 7,3\% yang terdiri dari 5,7\% gemuk dan 1,6\% obesitas. Dari data Riskesdas tersebut menunjukkan bahwa terjadi kenaikan prevalensi obesitas pada remaja di Indonesia (Riskesdas, 2013). 
Journal of Healthcare Technology and Medicine Vol. 4 No. 1 April 2018

Universitas Ubudiyah Indonesia

e-ISSN : 2615-109X

Prevalensi IMT Aceh usia >15 tahun adalah Kurus 13,1 \%, Normal 70,3\%, BB lebih 8 $\%$, Obesitas 8,6 \%. Berdasarkan perbedaan menurut jenis kelamin menunjukkan bahwa obesitas pada laki-laki adalah 5,2 \%, sedangkan pada perempuan adalah 11,7\% . Di Banda Aceh Prevalensi laki-laki adalah 14,6\%, dan perempuan 21,4\% (Riskesdas, 2007).

Aktivitas fisik akan membakar energi dalam tubuh sehingga jika asupan kalori ke dalam tubuh berlebihan dan tidak diimbangi dengan aktivitas fisik yang seimbang akan menyebabkan tubuh mengalami kegemukan (Mahmudiono, 2013).

Berdasarkan hasil skrinning awal di SMAN 4 Banda Aceh yang dilakukan oleh peneliti terhadap 529 populasi pada pelajar kelas X dan XI ditemukan bahwa sekitar 2,26 \% obesitas pada pelajar kelas X dan XI yang bersekolah di SMAN 4 Banda Aceh. Berdasarkan uraian diatas, peneliti tertarik untuk melakukan penelitian mengenai "Faktor-Faktor yang berhubungan dengan Kejadian Obesitas pada Pelajar di SMAN 4 Banda Aceh”.

\section{METODE PENELITIAN}

Jenis penelitian ini adalah penelitian yang bersifat deskriptif analitik dengan menggunakan desain cross sectional yaitu pengukuran atau observasional data variabel independen dan dependen dilakukan pada saat yang bersamaan (Nursalam 2013).

Dalam penelitian ini peneliti ingin melihat Faktor-faktor yang berhubungan dengan Kejadian Obesitas pada Pelajar di SMAN 4 Banda Aceh.

Populasi dalam penelitian ini adalah pelajar kelas X dan XI yang ada di SMAN 4 Banda Aceh yang berjumlah 529 pelajar. Data identitas sampel diperoleh langsung dengan metode wawancara langsung kepada sampel dengan menggunakan kuisioner, yang meliputi data nama, umur, jenis kelamin, tingkat pendidikan dan alamat.

Data antropometri yang dikumpulkan yaitu data penimbangan berat badan dan data pengukuran tinggi badan. Berat badan diukur menggunakan timbangan injak digital dengan kapasitas $150 \mathrm{~kg}$ dan ketelitian 0,1 kg. Sedangkan tinggi badan diukur menggunakan microtoice dengan kapasitas $200 \mathrm{~cm}$ dan ketelitian $0,1 \mathrm{~cm}$. Data yang dikumpulkan adalah penimbangan berat badan dan pengukuran tinggi badan, asupan makanan dan aktivitas fisik, pola makan dan jenis kelamin. 
Journal of Healthcare Technology and Medicine Vol. 4 No. 1 April 2018

Universitas Ubudiyah Indonesia

e-ISSN : 2615-109X

HASIL DAN PEMBAHASAN

Hubungan Jenis Kelamin dengan Kejadian Obesitas pada Pelajar

Tabel 1 Hubungan Jenis Kelamin dengan Kejadian Obesitas pada Pelajar di SMAN 4 Banda Aceh Tahun 2018

\begin{tabular}{|c|c|c|c|c|c|c|c|}
\hline \multirow{3}{*}{$\begin{array}{l}\text { Jenis } \\
\text { Kelamin }\end{array}$} & \multicolumn{4}{|c|}{ Obesitas } & \multicolumn{2}{|c|}{ Total } & \multirow[t]{2}{*}{$p$ value } \\
\hline & \multicolumn{2}{|c|}{ Obesitas } & \multicolumn{2}{|c|}{$\begin{array}{c}\text { Tidak } \\
\text { Obesitas }\end{array}$} & & & \\
\hline & $\mathrm{n}$ & $\%$ & $\mathrm{n}$ & $\%$ & $\mathrm{n}$ & $\%$ & \\
\hline Laki-laki & 23 & 62,2 & 14 & 37,8 & 37 & 100 & 0,006 \\
\hline Perempuan & 14 & 29.8 & 33 & 70,2 & 47 & 100 & \\
\hline
\end{tabular}

Berdasarkan tabel di atas menunjukkan bahwa dari 37 responden yang berjenis kelamin laki-laki mengalami obesitas sebanyak 23 responden $(62,2 \%)$ dan dari 47 responden yang berjenis kelamin perempuan mengalami obesitas sebanyak 14 responden $(29,8 \%)$.

Hasil uji statistik diperoleh $p$ value $=0,006<0,05$. Sehingga dapat disimpulkan bahwa ada hubungan jenis kelamin dengan kejadian obesitas pada pelajar di SMAN 4 Banda Aceh Tahun 2018.

Hubungan Asupan Serat dengan Kejadian Obesitas pada Pelajar

Tabel 2 Hubungan Asupan Serat dengan Kejadian Obesitas pada Pelajar di SMAN 4 Banda Aceh Tahun 2018

\begin{tabular}{|c|c|c|c|c|c|c|c|}
\hline \multirow{3}{*}{ Asupan Serat } & \multicolumn{4}{|c|}{ Obesitas } & \multirow{2}{*}{\multicolumn{2}{|c|}{ Total }} & \multirow{2}{*}{$p$ value } \\
\hline & \multicolumn{2}{|c|}{ Obesitas } & \multicolumn{2}{|c|}{$\begin{array}{c}\text { Tidak } \\
\text { Obesitas }\end{array}$} & & & \\
\hline & $\mathrm{n}$ & $\%$ & $\mathrm{n}$ & $\%$ & $\mathrm{n}$ & $\%$ & \\
\hline Kurang & 36 & 67,9 & 17 & 32,1 & 53 & 100 & 0,001 \\
\hline Cukup & $\underline{1}$ & $\underline{3}, 2$ & $\underline{30}$ & $96 \underline{2}, \underline{8}$ & $\underline{31}$ & 100 & \\
\hline
\end{tabular}

Berdasarkan tabel di atas menunjukkan bahwa dari 53 responden dengan asupan serat kurang mengalami obesitas sebanyak 36 responden $(67,9 \%)$ dan dari 31 responden dengan asupan serat cukup mengalami obesitas sebanyak 1 responden $(3,2 \%)$

Hasil uji statistik diperoleh $p$ value $=0,001<0,05$. Sehingga dapat disimpulkan bahwa ada hubungan asupan serat dengan kejadian obesitas pada pelajar di SMAN 4 Banda Aceh Tahun 2018. 
Journal of Healthcare Technology and Medicine Vol. 4 No. 1 April 2018

Universitas Ubudiyah Indonesia

e-ISSN : 2615-109X

Hubungan Pola Makan dengan Kejadian Obesitas pada Pelajar

Tabel 3 Hubungan Pola Makan dengan Kejadian Obesitas pada Pelajar di SMAN 4 Banda Aceh Tahun 2018

\begin{tabular}{|c|c|c|c|c|c|c|c|}
\hline \multirow{3}{*}{ Pola Makan } & \multicolumn{4}{|c|}{ Obesitas } & \multirow{2}{*}{\multicolumn{2}{|c|}{ Total }} & \multirow[t]{2}{*}{$p$ value } \\
\hline & \multicolumn{2}{|c|}{ Obesitas } & \multicolumn{2}{|c|}{$\begin{array}{c}\text { Tidak } \\
\text { Obesitas }\end{array}$} & & & \\
\hline & $\mathrm{n}$ & $\%$ & $\mathrm{n}$ & $\%$ & $\mathrm{n}$ & $\%$ & \\
\hline Tidak baik & 27 & 69,2 & 12 & 30,8 & 39 & 100 & 0,011 \\
\hline Baik & $\underline{10}$ & $\underline{22}, \underline{2}$ & $\underline{35}$ & $77, \underline{8}$ & $\underline{45}$ & 100 & \\
\hline
\end{tabular}

Berdasarkan tabel di atas menunjukkan bahwa dari 39 responden dengan pola makan tidak baik mengalami obesitas sebanyak 27 responden $(69,2 \%)$ dan dari 45 responden dengan pola makan baik mengalami obesitas sebanyak 10 responden $(22,2 \%)$

Hasil uji statistik diperoleh $p$ value $=0,011<0,05$. Sehingga dapat disimpulkan bahwa ada hubungan pola makan dengan kejadian obesitas pada pelajar di SMAN 4 Banda Aceh Tahun 2018.

\section{Hubungan Aktivitas Fisik dengan Kejadian Obesitas pada Pelajar}

Tabel 4 Hubungan Aktivitas Fisik dengan Kejadian Obesitas pada Pelajar di SMAN 4 Banda Aceh Tahun 2018

\begin{tabular}{|c|c|c|c|c|c|c|c|}
\hline \multirow{3}{*}{$\begin{array}{c}\text { Aktivitas } \\
\text { Fisik }\end{array}$} & \multicolumn{4}{|c|}{ Obesitas } & \multirow{2}{*}{\multicolumn{2}{|c|}{ Total }} & \multirow{3}{*}{$p$ value } \\
\hline & & itas & & Tidak & & & \\
\hline & \multicolumn{4}{|c|}{ Obesitas } & & & \\
\hline & & & $\%$ & $\mathrm{n}$ & $\%$ & $\mathrm{n}$ & $\%$ \\
\hline Ringan & 27 & 50,9 & 26 & 49,1 & 53 & 100 & \\
\hline Sedang & 10 & 34,5 & 19 & 65,5 & 29 & 100 & 0,001 \\
\hline Berat & 0 & 0 & 2 & 100 & 2 & 100 & \\
\hline
\end{tabular}

Berdasarkan tabel di atas menunjukkan bahwa dari 53 responden yang memiliki aktivitas ringan mengalami obesitas sebanyak 27 responden (50,9\%), dari 29 responden memiliki aktivitas fisik sedang mengalami obesitas sebanyak 10 responden $(34,5 \%)$ dan dari 2 responden yang memiliki aktivitas fisik berat tidak ada yang mengalami obesitas. 
Journal of Healthcare Technology and Medicine Vol. 4 No. 1 April 2018

Universitas Ubudiyah Indonesia

e-ISSN : 2615-109X

Hasil uji statistik diperoleh $p$ value $=0,001<0,05$. Sehingga dapat disimpulkan bahwa ada hubungan aktivitas fisik dengan kejadian obesitas pada pelajar di SMAN 4 Banda Aceh Tahun 2018.

Kebanyakan pelajar hanya melakukan aktivitas fisik ringan sampai sedang, keseharian pelajar didominasi dengan aktivitas fisik yang sangat sedikit mengeluarkan energi seperti mayoritas pelajar kesekolah menggunakan motor, diantar maupun menggunakan bus transkutaraja. Sedikit sekali pelajar yang tertarik berolahraga yang membutuhkan pengeluaran energi yang banyak (aktivitas berat) baik mengikuti ektrakulikuler di sekolah maupun di luar sekolah, tradisi nongkrong di kafe duduk berjam-jam hanya sambil mengobrol dan untuk mengetahui berbagai informasi pelajar cukup menggunakan gadget tanpa harus bepergian ke pusat informasi tersebut.

Menurut peneliti obesitas tidak hanya disebabkan oleh faktor jenis kelamin, namun obesitas juga dipengaruhi oleh faktor yang lainnya, seperti asupan makanan yang berlebih, asupan kurang serat yang kurang, pola makan yang tidak baik dan aktivitas fisik yang kurang.

Berdasarkan hasil penelitian pelajar lebih sering mengkonsumsi jenis makanan yang memiliki nilai gizi kurang baik, karena pelajar lebih banyak menghabiskan waktu di luar rumah, berdasarkan hasil penelitian sebagian besar pelajar mengkonsumsi fastf ood lebih dari 5 kali dalam seminggu, karena tidak dapat dihindari jajanan yang ada di sekolah sebagian besar tergolong dalam fast food seperti bakso goreng, siomay, mie caluk, mie aceh, mie instan, batagor, fried chicken.

Menurut peneliti sebagian besar pelajar sangat sedikit dan bahkan jarang sekali melakukan aktivitas fisik yang mengeluarkan energi berlebih. Setiap berangkat ke sekolah atau bepergian pelajar menggunakan kendaraan baik itu dengan jarak tempuh yang jauh bahkan dekat sekalipun, disamping itu hanya sebagian kecil dari pelajar yang berolahraga, bahkan untuk pelajar putri hampir tidak ada yang melakukan olahraga.

\section{KESIMPULAN}

1. Ada hubungan jenis kelamin dengan kejadian obesitas pada pelajar di SMAN 4 Banda Aceh Tahun 2018 ( $p$ value $=0,006$ ).

2. Ada hubungan asupan serat dengan kejadian obesitas pada pelajar di SMAN 4 Banda Aceh Tahun 2018 ( $p$ value $=0,001)$. 
Journal of Healthcare Technology and Medicine Vol. 4 No. 1 April 2018

Universitas Ubudiyah Indonesia

e-ISSN : 2615-109X

3. Ada hubungan pola makan dengan kejadian obesitas pada pelajar di SMAN 4 Banda Aceh Tahun 2018 ( $p$ value $=0,011)$.

4. Ada hubungan aktivitas fisik dengan kejadian obesitas pada pelajar di SMAN 4 Banda Aceh Tahun 2018 ( $p$ value $=0,001)$.

\section{DAFTAR PUSTAKA}

Proverawati. 2010. Obesitas dan Gangguan Perilaku Makan pada Remaja. Yogyakarta: Nuha Medika

Muchtadi, D. (2001). Pencegahan Gizi Lebih dan Penyakit Kronis Melalui Perbaikan Pola konsumsi Pangan. Bogor: Jurusan Teknologi Pangan dan Gizi Fakultas Teknologi Pertanian Institut Pertanian Bogor.

Notoatmodjo, S. (2010). Metodologi Penelitian Kesehatan. Jakarta: Rineka Cipta 